\title{
Preventing Radicalism through Introducing Multicultural Values on Indonesian Novels with Minangkabau Color
}

\author{
Amar Salahuddin \\ Universitas Dharmas Indonesia (UNDHARI) \\ salahuddin.amar@hotmail.com
}

\begin{abstract}
This research was based on several radical behaviour found in society. These radical actions need more serious attention by all community. This research aimed at describing kinds of preventive radicalism through multicultural of Minangkabau colorednovels. This research was qualitative through analysis descriptive method. Source of the data were got from multicultural values of Indonesian novels local color Minangkabau, interview, and documentation both of text, soft file, and other documents that related to research of preventive radicalism through planting multicultural values of Indonesian Minangkabau colored-novels. Technique data collections were done through observation, interview, and documentation. Meanwhile data analysis uses descriptive analysis method qualitatively that has 3 analysis components, as follows: data reduction, data display, and conclusion. Then, to check the validity of data, researcher used 3 criteria of validity of data: credibility, dependability, and conformability. The result shows that on Minangkabau colored-novels was found multicultural values, as follows: learning life value in difference (tolerance), building mutual-trustworthiness value, maintenance respectable value, open thinking value, appreciation and interdependent values. By planting multicultural values, teachers and learners are hoped to be able live together differently, to apply learning democracy in a class, and to plant cultured intelligence, this is one of preventions of radicalism, and all these preventions can be applied in formal and informal education.
\end{abstract}

Keywords--Radicalism, Multicultural, Novel, Local Color, Minangkabau.

\section{INTRODUCTION}

Terrorism often occurs along with particular ideology. It begins with intolerance and then goes to radicalism and finally come to suicidal bombing, terror attack, and any acts of violence. On the principle, they do not accept differences; they only feel own them right, blame everything and everyone out of themselves, their groups, their beliefs, moreover they easily turn on right the false of their views about jihad that is full of violence in peace situation.

Ministry of religion, along with Analytical and Capacity Development Partnership (ACDP), have published their research, there is a painful fact that $30 \%$ students of elementary schools up to senior high school in Indonesia get influence radicalism values. Result of this research is very surprising and of course, it can be denied that it becomes a huge code for this nation and country. We cannot ignore the result of research if we do not involve in surplus radicalism situation.

The head of BNPT (national antiterrorist association) Komjen Pol Suhardi Alius (in Akbar, 2016 CNN Indonesia) says that radicalism has infiltrated to some well-known universities in Indonesia. He asks to officials of each university to enhance monitoring of students' activities, especially exclusive students' organizations. The spread of radicalism is also sophisticated, recently this group use social media to do propaganda and indoctrination to society or particular targets.

Meanwhile, a LIPI researcher, Anas Saidi (in Lestari 2016, BBC Indonesia) states that radicalism occurs because islamization process done by young people that happen closely, and tend to not open to others Islamic views, moreover to different religions, and different beliefs. If this understanding let, it can cause disintegration nation because they view Pancasila (the principle concept of Indonesia) ideology is not important anymore. Anas, in his research in 2011 in 5 universities in Indonesia, UGM, UI, IPB, Unair, Undip shows that there is increasing understanding of conservative and fundamentalism religions, especially in general university students. Radicalism among of students and students college happen after reformation, through Jamma'ah Tarbiyah (Ikhwanul Muslimin), including HTI and Salafi (part of international Islamic action) and then most of general universities, dominated by Ikhwanul Muslimin and other Islamizations. If this understanding let, it can fertilize intolerant attitude and can cause disintegration a nation. Islamization process done by the young people happens closely, and tends not to open on other Islamic views.

Based on data delivered by (in Lestari 2016, BBC Indonesia), a survey of Islamic discussing and Peace, lead by Prof. Dr. Bambang Pranowo, Islamic sociology at UIN (Islamic University) Jakarta, October 2010 - January 2011, states that almost $50 \%$ students agree radical action. Data got, $25 \%$ students and $21 \%$ teachers shows that Pancasila is not relevant anymore. Meanwhile $84.8 \%$ students and $76.2 \%$ teachers agree with applying Islamic rules in Indonesia. total 
numbers of agree to violence for religious solidarity reaches $52.3 \%$ students and $14.2 \%$ agree with bomb attack. Then, on the Pew Research Center in 2015 ago, reveals that in Indonesia, more or less $4 \%$ or about 10 million Indonesian people support ISIS, most of them are teenagers..

Radicalism can be spread as found by ACDP, Zaini (2017) records, at least there 3 main factors of spreading the radicalism. First, today, we involve of a new era called "Kemarau Spiritualitas". Religion becomes a need to be leaned on in postmodern era that it makes people far away from beliefs values; it can be trusted as a transcendent power. It means that religion becomes "Pelarian" (escapee) in middle of this era.

Second, situation need towards religion as the "pelarian" (escapee) does not control by their parents. It means that, their parents tend careless in monitoring the development of their children understanding of religion: from elementary school up to university level.

Third, religious teachers competency is not knowledgeable and it causes students find teachers out of school activities. Therefore, it creates an extracurricular activities, it is called rohis. It starts to grow the radicalism.

PPIM (Islamic center discussing and humanity) UIN Syarif Hidayatullah Jakarta (in Mohammad, 2017) has done a research: "Guru Agama" (religious teacher), tolerance, and issues of religious life contemporary in Indonesia on December $15^{\text {th }}, 2016$. PPIM researcher claims that result of the research cannot use for generalizing various attitude and nation all Islamic teachers in Indonesia. This research got respondents that were teachers of Islamic religion in 11 regencies among 5 provinces: Aceh Besar, Pidie, garut, Tasikmalaya, Ciamis, Solo, Mataram, Lombok Timur, Makassar, Maros, and Bulukumba. There were 175 respondents, interviewed qualitatively method and 330 respondents through quantitatively.

Threat of radicalism and terrorism are still happening until right now. The effects of radicalism and terrorism are not only make fearfulness but also trauma and then interrupt national stability. In doing indoctrination activities, a group of terrorism often does it rely on the name a certain religion. This group claims that the only truth for their group and feels they much more understand about religious doctrine.

Radicalism as terminology is original word from Latin "radix", it means a root. In English word of radical means extreme, whole, fanatic, revolutionary, ultra, and fundamental. Meanwhile radicalism means doctrine or practicing understanding radicalism or understanding extreme (M. Nuh, 2009). Based on Indonesia dictionary (KBBI) radicalism means (1) understanding or radical grouping in politic: (2) understanding or a group that want a change or social change and politic along with violently or dramatically; (3) extreme attitude in political grouping. Meanwhile, according to Ghufron (2017), radicalism is an understanding that desires dramatically a change or a renewal until the top way. Moreover, to reach the goals, it involves many extreme ways: violence both symbolic and physical.

Therefore, radicalism is a general symptom that can be happened in society along with various motives: social, politic, culture, and religion, signed by radical action, extreme, and anarchy as rejection of symptom faced. However, it needs to be recorded that several understanding radicalism is not only by radical actions and anarchy. In reality, it can be found that some group of radical actions only limit to thinking and ideology, and not to use violence ways in doing their beliefs, but some group of radical actions make right of the violence in fighting their beliefs. Thus radical religious actions are not indicated by anarchy or terrorism.

Muqoyyidin (2013) defines that one of his programs, is by deradikalisasi program through Islamic education through inclusive-multicultural. On this occasion, they need to concern to curriculum factor, educator, and learning strategy used. Then, according to Pageh (2016), on his research about Pura Negara Gambur Angala is a monument in religious context, becomes integrative factor for various religious people, ethnic, and culture that has a characteristic of cross culture in Bali Utara. Learning by history, integrative factor, a part of local wisdom is very suitable to be an educational model of multiculturalism, and then it useful for research a link of Indonesia nation future to prosperity and safety (gemah ripah loh jinawi).

Multicultural society is society, consists of many cultures and between supporting cultures that respect each other. Meanwhile multiculturalism is an understanding that various cultures have the same level. Term of multicultural is introduced at first as a concept of anthropology that it has occurred "monoculturalism" as institutional ideology in AS ((Desai, 2000; Closson, 2008).

Multicultural means "multi" as plural, "kulturalisme" means culture. (Tilaar, 2004, p.387) defines that multicultural means institutional of various cultures that own by a group of ethnic in a nation-state through low system, education, government policy, language, religious activities and other fields. Based on Parekh (2009, p.19), a multicultural society is society that involves 2 or more cultural society. Term of multicultural refers to a normative respond on the fact. Mahmud (2006) says that multicultural is a concept live together that confesses multiple diverse, difference, and various cultures; tribe, ethnic, religion, and etc. referring with explanations above, it can be said that multicultural is an attitude and a manner of respectful the differences and various cultures. 
Local color is also involving developing of Indonesian literature. In 1980 era, the local color tended in Indonesian literature. This development proves that Indonesian literature has variation cultures. Generally, Indonesia literature has local color written by local people that live in those areas, except areas such as, Dayak, Jawa, and Bali. Minangkabau, one of Indonesia regions and tribes, often appears in literature. Minangkabau is a rich region along with cultures values and it is often used as creating literature. In Indonesian literature development, Minangkabau culture has important position. High culture value becomes one of supported factor, and also there is graciousness those values and level mobility of Minangkabau society itself (Esten, 1983, p. 221)

Local color requires specific characteristic that does not have by anything out of local color itself. Abrams (1981, p. 1989) defines that this local color is precise painting about background, dialect, custom, how to dress, how to think, how to feel, and etc that has specific character by a certain region in a history. Kusmarwati (2008) states that to understand local color, Minangkabau, it is needed knowledge about condition of social culture of its society. Condition of social culture of Minangkabau society can be seen such as marriage process, family relationship, social organization, system of society, beliefs, mean of support, custom, and art changing, individual society, and self esteem.

Pinurbo (Admin, 2017) states that literature approach is very important because recently, young people grow in a bad situation. Recently, young people grow uncivilized of social media. One ways to fight terrorism is through art and literature. In line with Pinurbo, Imran also states that literature and art guide to humanitarian sense. Humanitarian sense should be in politics and religion. However, recent politics has lost its humanitarian sense. There are many types of radicalism such as religious spirit, radical market, and radical financial capital.

Literature can develop logical reasoning as preventive and can become articulation to reach the peace. By a beauty of literature possessed, can someone in influencing thought to prevent radicalism and terrorism. Through literature work such as poem, poetry, short story, novel, are expected to contribute to the strengthening of prevention efforts of terrorism now and in the future. Literary works, believed to attract public attention. The beauty of literature can also have a positive effect, as a peaceful way of preventing radicalism from becoming a source of terrorism.

Indonesia is a complex nation, ethnic, religious, racial, and various other interests. The implications of the mismatch of cultural buildings are still visible with the many conflicts, violence, and various social fights that cause many victims and losses. Nevertheless, in the last decade Indonesia has entered a new era, commonly referred to as "era reformasi". Generally, changing power of new era, changing the political, social, and cultural era, thus changing the problems faced by the people and Indonesia.

Referring with multicultural ideology, novel also has the potential to become a model literacy of multicultural society in Indonesia. By process of searching and forming, novel takes an important role. Novel is a social institution with mediated language. In certain theory, a novel is a response and representation a model of life commonly referred to as a secondary modeling system (Lotman, 1977). Actually, Indonesian literature, multicultural, has essentially existed since the beginning of XX century, although at that time, multicultural has not been used by society. By the author's life view which is part of society, multicultural problems are raised and responded. Furthermore, when the novels are got by the readers, it is expected to be an inspiration and of course, to be a multicultural society model in Indonesia.

Six novels used as objects and discussed later are some of the many novels that correlate with the multicultural and a part of Indonesian novels of local Minangkabau color. Reason why the researcher chose these six novels, pre-war novels such as Novel Salah Asuhan by Abdul Muis, Tenggelamnya Kapal Vander Wijck by Hamka, and Sitti Nurbaya by Marah Rusli. These three novels are the main and the peak of Balai Pustaka era, the novels have offered multicultural ideas that were more popular with the term kebinnekaan. Then, these novels after war were Kemarau written by AA Navis, OrangOrang Belanti by Wisran Hadi, and Kusut by Ismet Fanany. The problems raised by these novels reflect the various concepts that be struggle or saved by multicultural, multicultural novels that represent its time and the local color of Minangkabau is an ethnic strong in Indonesia that give birth to great writers and monumental works. This is the main reason for selecting of the three novels above.

Meanwhile, scarce information or even lack of clear formulation of novel position in relation to multicultural developments in Indonesia supports the originality of this study. In line with that opinion, Taufiq (2014) also says that Multicultural literature is as an important and strategic study in participating, answering the nation's problems. This research uses multicultural theory formulated by Tilaar (2004) that is multicultural values about learning to live in difference (tolerance), building mutual trust, maintaining mutual respect, opening minded, and appreciating and interdependence.

Development of understanding radicalism, of course it is needed to be taken preventive steps. One of them is to introduce and apply multicultural education. Thus, by planting the multicultural values of literature works of Indonesian novels local Minangkabau colors such as, multicultural values of learning to live in differences (tolerance), building mutual trust, maintaining mutual respecting, opening minded, and appreciating and interdependence. Therefore, it is clear that the study of preventive radicalism through the Implementation of multicultural values Indonesian novels local colors 
Minangkabau aims at describing the preventive radicalism through multicultural values in Indonesian novels of local color Minangkabau and its urgency is as a glue of diversiy (kebinekaaan) for environmental wisdom that must be supported and cultured.

\section{METHODS}

This research was qualitative research by using descriptive analysis method. In this research, researcher was as an instrument: as an interviewer and an observer. Data of this research was obtained from the research of multicultural values in the Indonesian novel through local color of Minangkabau, interview and documentation through text, soft files and other documents focused on research prevention of radicalism through the planting of multicultural values in Indonesian novels of Minangkabau's local color. Technique of collecting data of this research was by observation, interview, and documentation. After getting the data through several methods, the researcher processed and analyzed the data by using descriptive analysis with qualitative methodology approach. Data analysis was done by organizing and reviewing systematically from all data obtained. The purpose of the analysis was to narrow and limit the findings to become regular, well-ordered and more meaningful data (Marzuki, 2000, p. 87).

In order to satisfying results of this research can be arranged systematically, then research step in analyzing the data is started by reviewing all available data from various sources: interviews, observation, and documentation. The data got, of course, are very much, after reading and studying, the next step is to involve three components of analysis, namely: (1) data reduction, (2) data presentation (data display), and (3) verification. The three components of the analysis are interactive. At the data reduction stage, categorization and data groupings are more important, meaningful, and relevant to the purpose of the study, so that the final conclusion can be drawn and verified. Meanwhile, at the data presentation stage uses the analysis of themes, graphs, matrix and table. Therefore, the data presented is more interesting and easily understood, either by itself or by others. Then, conclusion is done by techniques looking for patterns, themes, relationships, equations, and things that often appear.

\section{FINDING AND DISCUSSION}

This section contains the multicultural values in Indonesian novels of local color Minangkabau. The multiculturalism experienced by the main character in Novel Salah Asuhan by Abdul Muis, Tenggelamnya Kapal Van Der Wijck by Hamka, Sitti Nurbaya by Marah Rusli, Kemarau by A.A Navis, Orang-orang Blanti by Wisran Hadi, and Kusut by Ismet Fanani. Hanafi, Corrie, Mariam, Samsulbahri, Sitti Nurbaya, Zainuddin, and Hayati, Desna, Bu Yuk, Pak Eko, appear when they socialize with people of different customs, cultures, regions, religions, people from different regions and countries that have different characters, customs and cultures. Differences and cultural diversity or multicultural that can lead to the emergence of values multiculturalism to the main character. Multicultural values occur in several forms such as the value of learning to live in differences (tolerance), the value of building mutual trust, the value of maintaining mutual respect, the value of open in thinking, and the value of appreciation and interdependent.

Furthermore, this section contains multicultural values in multiethnic community life and the planting of multicultural values through formal and informal education.

1. Multicultural values in Multi-ethnic society

Multicultural is understood not only as diversity, but also construction to create a harmonious life, designed to understand and appreciate that differences. Multiculturalism demands people to live in tolerance, mutual understanding between cultures and between nations in fostering a new world. Thus, multicultural can contribute the sense of love to others and as a tool to foster a safe and prosperous world. In the multicultural, the nations sit together, respect each other, help each other, and do not see whether a community group is a majority or a minority so that, there is no majority domination and minority tyranny. Understanding human in understanding multiculturalism will provide a great role and contribution to the development of a better world. A nation that is not only thinking about its generation, but also it is able to pass on a better life for future generations.

Indonesia is a nation that kinds of multiethnic and multicultural nation. Recently, there are more than 500 ethnic groups using more than 250 languages. Each ethnic does not stand as a closed and independent entity, but interacts with each other and interdependent, and interplay with one another. This social interaction formed with this diversity requires a cross-cultural understanding and trust in each party involved in the interaction and is a social capital for the establishment of a healthy, prosperous and prosperous inter-ethnic relationship. Multiculturalism is more common in modern society living in urban areas in Indonesia. Modern society is a society that most of its citizens have orientation of cultural values directed to life in civilization today. In general, modern people live in urban areas so called urban communities. 
Planting multicultural values in multiethnic society in Indonesia needs to be applied immediately. One of planting multicultural values can be seen in novels: Salah Asuh, Tenggelam Kapal Van Der Wicjk, dan Sitti Nurbaya, Kemarau, Orang-orang Blanti, and Kusut. On those novels, can be seen the reflection of main characters that can live together in multicultural society from various regions, tribes, races, and countries.

2. Planting multicultural values through formal and informal education

Multiculturalism has a big role in nation building. Indonesia as a country that stands on the diversity of culture, it is very important to understand multicultural in every step that will be taken for the development of the nation. With this multicultural, then the principle of "Bhinneka Tunggal Ika" as listed in the state base will be realized. Cultural diversity owned by the nation of Indonesia will be an inspiration and potential for the nation's development thus dreams of Indonesian society such as equitable, wealthy, and safe can be achieved.

The cultivation of these multicultural values can be done through formal and informal education. The following, it describes the cultivation of multicultural values through formal education.

1. Building a paradigm of diversity of inclusion in school environments.

Teachers and school policy must accept that there are other religions out of their religions. There are followers of religion other than themselves who also embrace a religion. There are many students that are different religions at school thus schools must serve the spiritual activities of all their students well. Eliminate sense of the majority of minority students according to their religions.

2. Appreciate the various languages at school

School consists of teachers, stuffs, and students from different regions with a various languages, dialects and speech. Although there is Indonesian language as a formal introduction at school but the accent or style of speech always appears in every language expression, both oral and written. Schools need to have rules that accommodate respect for language differences.

3. Building a critical understanding and empathy for social differences

Educational services and enforcement of school regulations should not concern into students' social status. Join students from different social statuses in groups and classes to normal interaction at school. Nevertheless, teachers and students must still understand the social differences that exist between their peers. This understanding is not to create differences, attitudes higher than others, or low self-esteem for the less, but to plant a sense of thank for everything.

4. Building an anti-ethnic discrimination attitude

Schools can be mini Indonesia or mini world, where various ethnic students study at school. At school, it could be a majority ethnicity against other ethnicities. It should be understood that in other schools, ethnic originally the majority can be a minority. Avoid negative attitudes toward different ethnicities.

5. Respect for differences in ability

At school, not all students are equal. In social psychology is known as the term disability, it means, there is a physical and mental conditions that make students mix between superior and weak students in groups or classes in order to peer guidance.

6. Appreciating the age differences

Every student faces physical growth and psychological development based on age development. Teacher must understand this, especially about the psychological characteristics and level of ability according to age. Older people should give a good example, motivated, confidence, and protect the younger ones while the young respect, and imitate them.

In addition through formal education, the planting of multicultural values can also be applied through informal education. The following describes the planting of multicultural values through informal education.

1. Planting in every child that we live surrounded by different religion, ethnicity, race and intergroup, by socializing well with neighbors so they can learn to accept the difference with a fun process thus children feel the difference is not a problem but a gift.

2. Developing a children's interest to things that are not principal, such as culture or other habits, work, or other interesting things. A sense of interest in diversity can motivate children to know through reading, searching on the internet, visiting, asking more informed ones, and so on.

\section{CONCLUSION AND RECOMMENDATION}

It should be realized, to overcome radicalism is not a job that can be done easily. It needs close teamwork between the various elements thus the notion of radicalism does not thrive in educational institutions. It needs to be careful, if there are members of the school community and college that show symptoms of radicalism indicated syndrome, which appears in the physical characteristics and way of thinking. By so many terrorism actions in Indonesia, it is concrete evidence how the security use approach is not effective enough to eradicate terrorism and Islamic radicalism to its roots. Therefore, various 
approaches to the handling of terrorism and other Islamic radicalism must also always strived, one of them is trough literature works, and it believed to be able to suck the public's attention. The beauty of literature can also have a positive effect, as a peaceful way of preventing radicalism from becoming a source of terrorism. Literature as a branch of art is an important element of refining feelings, shaping personal and social sensitive nature, and respecting human values. The literary works of Indonesian novels of Minangkabau local color contain Multicultural values. Multicultural values occur in several forms such as the value of learning to live in differences (tolerance), the value of building mutual trust, the value of maintaining mutual respect, the value of open in thinking, and the value of appreciating and interdependence.

The planting of multicultural values in the life society of multi-ethnic communities in Indonesia needs to be applied as early as possible. One example of the application of multicultural values can be seen in the novel Salah Asuhan, Tenggelam Kapal Van Der Wicjk, and Sitti Nurbaya, Kemarau, Orang-orang Blanti, dan Kusut. These novel are illustrated how the characters of the story can co-exist with multicultural society originating from various regions, tribes, races, religions, and countries. The planting of these multicultural values can be done through formal and informal education. The following items describe the planting of multicultural values through formal education. 1) Building a paradigm of inclusive diversity at school environment. 2) Appreciating the various languages at schools. 3) Building a critical understanding and empathy for social differences. 4) Establishing an anti-ethnic discrimination stance. 5) Respecting differences in ability. 6) Appreciating the age differences.

\section{References}

Abrams, M.H. (1981). A glossary of literary terms. Cet. IV. New York: Holt, Rinehart, and Winston.

Admin. (2017). Sastra Efektif sebagai Penangkal Radikalisme dan Artikulasi Perdamaian. BNPT. https://www.bnpt.go.id/sastra-efektif-sebagai-penangkal-radikalisme-dan-artikulasi-perdamaian.html. Diakses 20 Mei 2018.

Akbar, W. (2016). "BNPT: Kelompok Radikal Bergerak di Sejumlah Kampus Ternama” CNN. https://www.cnnindonesia. com/ nasional/20160903110259-20- 155860/ bnpt-kelompok-radikal-bergerak-di-sejumlah-kampus-ternama. Diakses 14 Mei 2018.

Closson, D. (2008). "What Is Mult iculturalism" Stable URL: http://www.probe.org/content/view/778/169/. Diakses 15 September 2017.

Desai, D. (2000). "Imaging Difference: The Polit ics of Representation in Mult icultural Art Education" dalam Studies in Art Education, Vol. 41, No. 2, (Winter, 2000), pp. 114-129. Published by: National Art Education. Association Stable URL: http://www.jstor.org/stable/1320658. Diakses 15 September 2017.

Esten, M. (1983). Indonesia dan Minangkabau: eksistensi dalam perubahan. Horison, No. 2, Th. XVIII. Jakarta.

Ghufron, F. (2017)."Radikalisme dan Politik Identitas" Kompas. https://nasional.kompas.com/read/2017/05/05/19170871/ radikalisme.dan.politik.identitas. Diakses 16 Mei 2018.

Kusmarwanti. (2008). "Warna Lokal Minangkabau dalam Sastra Indonesia". Makalah Seminar PIBSI. Magelang: PIBSI.

Lestari, S. (2016). "Anak-anak muda Indonesia Makin Radikal?”. BBC. http://www.bbc.com/indonesia/berita indonesia/2016/02/160218_indonesia_radikalisme_anak_muda._Diakses 16 Mei 2018.

Lotman, J. (1977). The structures of the artistic text. Michigan: University of Michigan.

Mahfud, C. (2006). Pendidikan multikultural. Yogyakarta: Pustaka Belajar.

Marzuki. (2000). Metodologi riset. Yogyakarta : BPFE - UII.

Nuh, M., \& Nuhrison. (2009). Faktor-faktor penyebab munculnya paham/gerakan islam radikal di Indonesia. HARMONI: Jurnal Multikultural \& Multireligius, 8 (31) Juli-September 2009.

Mohammad, Y. (2017). Standardisasi pesantren membendung radikalisme. Berita tagar. https://beritagar.id/artikel/berita/standarisasi-pesantren-membendung-radikalisme. Diakses 16 Mei 2018.

Muqoyyidin, A. W. (2013). Membangun kesadaran inklusif-multikultural untuk deradikalisasi pendidikan islam. Jurnal Pendidikan Islam.Volume II Nomor 1 Juni 2013/ 1434. DOI: 10.14421/jpi.2013.21.131-151.

Navis, A. A. (1983). "Warna lokal minangkabau dalam sastra Indonesia mutakhir" Horison. Th. XIX . Jakarta.

Navis, A. A. (1994). "Warna lokal alam pikiran minangkabau dalam sastra Indonesia" Horison. No. 1, Th. XXVIII. Jakarta.

Nurgiyantoro, B. (1998). Teori pengkajian fiksi. Yogyakarta: Gajah Mada.

Pageh, I M. (2016). Multikulturalisme dan tantangannya di Indonesia: Jejak kesetaraan etnis dan kultur". Sosio Didaktika: Social Science Education Journal, Vol. 3 No. 2 Tahun 2016. DOI: http://dx.doi.org/10.15408/sd.v3i2.4344.

Parekh, B. (2009). Rethinking multiculturalism: keberagaman budaya dan teori politik. Yogyakarta: Kanisius.

Rubaidi, A. (2010). Radikalisme islam, nahdlatul ulama; masa depan moderatisme islam di indonesia. Yogyakarta: Logung Pustaka.

Sastrowardoyo, S. (1999). Konteks sosial budaya karya sastra. Jakarta: Balai Pustaka. 
Taufiq, A. (2014). Multicultural literature: The identity construction in Indonesian novels. Jurnal Humaniora. 26 (1) Februari. Hal. 22-31.

Tilaar, HAR. (2004). Multikulturalisme: Tantangan-tantangan global masa depan dalam transformasi pendidikan nasional. Jakarta: PT. Grasindo.

Voakes et al. (1996). Diversity in the news. A conseptual and methodological frame work. Jurnalism and Communication Quaterly. 73 (3).

Zaini, A., \& H. Faishal. (2017). Indonesia di pusaran radikalisme global. JawaPos. https://www.jawapos.com/read/ 2017/01/06/100372/indonesia-di-pusaran-radikalisme-global. Diakses 15 Mei 2018. 